Article

\title{
Analysis of Heavy Metal in Electrocoagulated Metal Hydroxide Sludge (EMHS) from the Textile Industry by Energy Dispersive X-Ray Fluorescence (EDXRF)
}

\section{Tanveer Mehedi Adyel ${ }^{1,2, *}$, Syed Hafizur Rahman ${ }^{3}$, Mala Khan ${ }^{4}$ and S.M. Nazrul Islam ${ }^{3,5}$}

1 School of Environmental Systems Engineering, The University of Western Australia, 35 Stirling Highway, Crawley, WA 6009, Australia

2 Department of Environmental Science, Z. H. Sikder University of Science \& Technology, Modhupur, Bhedergonj, Shariatpur 8024, Bangladesh

3 Department of Environmental Sciences, Jahangirnagar University, Savar, Dhaka 1342, Bangladesh; E-Mail: hafizsr@yahoo.com

4 Instrumentation and Calibration Service Laboratory (ICSL), Bangladesh Council of Scientific and Industrial Research (BCSIR), Dhaka 1205, Bangladesh; E-Mail: malakhan_07@yahoo.com

5 Department of Environmental Science and Engineering, School of Natural Resources and Environmental Studies, University of Northern British Columbia, 3333 University Way, Prince George, BC, V2N 4Z9, Canada; E-Mail: sislam0@unbc.ca

* Author to whom correspondence should be addressed; E-Mail: 21193926@student.uwa.edu.au; Tel.: +61-864-881-683; Fax: +61-864-881-105.

Received: 10 October 2012; in revised form: 20 November 2012 / Accepted: 23 November 2012 / Published: 3 December 2012

Abstract: Environmental pollution due to discharges of heavy metal containing sludge from textile industries is a common nuisance in Bangladesh, where no treatment of sludge is carried out before final disposals. Energy Dispersive X-ray Fluorescence (EDXRF) was employed in the present study to analyze the heavy metal content of Electrocoagulated Metal Hydroxide Sludge (EMHS) collected from a composite textile industry. Thirteen heavy metals, viz., $\mathrm{Mn}, \mathrm{Ti}, \mathrm{Cu}, \mathrm{Zn}, \mathrm{Ni}, \mathrm{Sr}, \mathrm{V}, \mathrm{Cr}, \mathrm{Zr}, \mathrm{Hg}, \mathrm{Cd}, \mathrm{Nb}$ and $\mathrm{Ga}$, were detected. $\mathrm{Mn}, \mathrm{Ni}, \mathrm{Cu}, \mathrm{Zn}$ and $\mathrm{Cd}$ exceeded the permissible limit to apply the EMHS in agricultural land. $\mathrm{Cr}, \mathrm{Ni}, \mathrm{Cu}$ and $\mathrm{Zn}$ were compared to the values of the European legislation to evaluate the environmental risk and to classify the wastes as inert wastes or as wastes that have to be control landfilled. EMHS was categorized as class I and needs to be deposited in controlled landfills. 
Keywords: electrocoagulation; textile sludge; X-ray optics; landfill; Bangladesh

\section{Introduction}

During the last few decades, parallel with rapidly developing technology, increasing population and urbanization, Bangladesh has been witnessing alarming environmental phenomenon all over the country. The growing load of environmental pollution gives rise to an increase in the number of so-called civilization damage that menaces the whole of mankind [1]. While industrialization, especially textile and dyeing, is often an integral part of economic development, rapid and unplanned growth may result in a wide impact on natural resources and the environment [2]. During the process of wastewater treatment in these industries, some by-products are generated and among them, the sludge stands out, because of the large volume and mass generated and for containing heavy, toxic and trace metals in its composition.

Electrocoagulated Metal Hydroxide Sludge (EMHS) is generated in situ within the reactor without direct addition of any chemicals during wastewater treatment by the electrocoagulation (EC) technique [3]. In EC, sacrificial anodes (aluminum or iron electrodes) corrode to release active coagulant precursors. Coagulant produces insoluble metallic hydroxide flocs, which can remove pollutants by surface complexation or electrostatic attraction [4]. As the textile industry uses different type of chemicals, salts, dye stuffs, resins, polymers, pigments, etc. in different stages of its operations, all the metals of such reagents are also removed by EC, and EMHS holds them. EMHS tends to be readily settable and easy to de-water, because it is composed of mainly metallic oxides/hydroxides and can be separated faster by filtration [4].

The degradation of the environment due to discharge of polluting sludge from textile industries is a real problem in several countries, and this situation is even worse in developing nations like Bangladesh, where little or no treatment of sludge is carried out before final disposals. Here, all types of sludge are disposed in landfill sites haphazardly or openly, leading to soil, surface water and groundwater contamination, and can pose a threat to natural resources, the environment and residents living within the immediate vicinity of the sludge disposal locations [5].

Very common heavy metals found in sludge include $\mathrm{Cd}, \mathrm{Zn}, \mathrm{Cu}, \mathrm{Cr}, \mathrm{Co}, \mathrm{Pb}, \mathrm{Mn}, \mathrm{Ni}, \mathrm{Hg}$, etc. [2,5-12]. These metals are very harmful, because of their non-biodegradable nature, long biological half-lives and their potential to accumulate in different body parts $[9,13,14]$. Metal-containing sludge application in agricultural land is risky, because these metals may be taken up by the crop roots and incorporated into the plant tissue. Ultimately, these toxic metals can get entrance into the human body and lead to bio-accumulation and bio-magnification. So excessive accumulation of heavy metals in agricultural soils through wastewater irrigation and sludge disposal may not only result in soil contamination, but also affect food quality and safety [15]. Health effects of these metals include kidney malfunction, the possibility of DNA damage or cancer development, damage to the central nervous system, reproductive failure, possibly even infertility, and so on $[9,16-18]$.

Among the various techniques for quantitative metal analysis, one of the most established ones is Energy Dispersive X-Ray Fluorescence (EDXRF). It is a relatively inexpensive, fast, non-destructive, 
multi-elemental technique and requires less procedural effort to run the system $[19,20]$. Its superiority is in less cumbersome sample preparation, and hence, it can be used for solid samples without any digestion. Moreover, in some favorable cases, the detection limit up to $1 \mathrm{ppm}$ can be reached [21]. EDXRF provides reliable results for both major and minor elements of samples when matrix effects are considered properly. EDXRF is applicable for wide ranges of fields, including environment, agriculture, archeology, soil, geology, etc. [22-30]. The present study analyzes heavy metal content in EMHS from the textile industry by EDXRF. Ultimately, this research will assess the suitability of EMHS for agricultural land application, landfill and other reuse options.

\section{Results and Discussion}

Detection limits of the instrument depend heavily on the type of sample matrix and the presence of any interfering elements at relatively high concentrations. The typical detection limit $(\mathrm{mg} / \mathrm{kg})$ of EDXRF was Cd (1), Cr (3), Cu (2), Mo (1), As (3), Mn (5), Ni (2), Pb (3), Hg (3), Zn (2) and Se (2). The method was validated comparing the analysis result with the reference value of NIST 2781 as given in Table 1.

Table 1. Analysis results of standard reference materials (NIST 2781) by EDXRF.

\begin{tabular}{cccccc}
\hline Metal & Reference Value (mg/kg) & Analysis Value (mg/kg) & Metal & Reference Value (mg/kg) & Analysis Value (mg/kg) \\
\hline $\mathrm{Cd}$ & 12.78 & 11.2 & $\mathrm{Ni}$ & 80.2 & 87.3 \\
$\mathrm{Cr}$ & 202 & 214.1 & $\mathrm{~Pb}$ & 202.1 & 214 \\
$\mathrm{Cu}$ & 627.4 & 664.2 & $\mathrm{Hg}$ & 3.64 & 3.3 \\
$\mathrm{Mo}$ & 46.7 & 39.3 & $\mathrm{Zn}$ & 1273 & 1301.4 \\
$\mathrm{As}$ & 7.82 & 8.8 & $\mathrm{Ag}$ & 98 & 94.3 \\
$\mathrm{Mn}$ & - & - & $\mathrm{Se}$ & 16 & 16.1 \\
\hline
\end{tabular}

A total of 13 heavy metals (Mn, Ti, Cu, Zn, Ni, Sr, V, Cr, Zr, Hg, Cd, Nb and Ga) were detected in the present study. $\mathrm{Mn}, \mathrm{Ti}, \mathrm{Cu}, \mathrm{Zn}$ and $\mathrm{Ni}$ content ranged from $0.23-0.98,0.48-0.67,0.34-0.78,0.28-0.34$ and $0.12-0.24 \mathrm{~g} / \mathrm{kg}$, respectively (Figure 1). The bottom and top of the boxes of the figure indicated the 25th and 75th percentile, respectively, while the dark line in the middle of the boxes denoted median. A high range of Mn content in EMHS made it unusable in agricultural land [2]. Mn was found as $3974.1 \mathrm{mg} / \mathrm{kg}$ in textile industry sludge in another study [2]. $\mathrm{Cu}, \mathrm{Ni}$ and $\mathrm{Zn}$ exceeded the recommended value in the case of industrial waste [31,32] and to apply in agricultural land [33]. Some well-documented studies disclosed that heavy metals, such as $\mathrm{Zn}$ and $\mathrm{Cu}$, were the principal elements restricting the use of sludge for agricultural purposes [34-36]. $\mathrm{Cu}, \mathrm{Ni}$ and $\mathrm{Zn}$ content in textile sludge in India was found to be 29, 167 and $264 \mathrm{mg} / \mathrm{kg}$, respectively [7], while 225, 89.67 and $186.5 \mathrm{mg} / \mathrm{kg}$, respectively, was found to be in chemical sludge [11]. Baskar et al. [12] found $\mathrm{Cu}$ and $\mathrm{Zn}$ concentration in common effluent treatment plant sludge to be 119 and $190 \mathrm{mg} / \mathrm{kg}$, respectively. The range of $\mathrm{Sr}, \mathrm{V}$ and $\mathrm{Cr}$ in EMHS was 52-88, 26-300 and 80-259 mg/kg, respectively (Figure 2). There are good uses of Cr-containing chemicals in the textile industry. During wastewater treatment by EC technique, these metals are also removed and accumulated in EMHS. Cr was found to be $1197 \mathrm{mg} / \mathrm{kg}$ in sewage sludge [6], $537 \mathrm{mg} / \mathrm{kg}$ in textile sludge [7], $358 \mathrm{mg} / \mathrm{kg}$ in common effluent plant sludge [11] 
and $14.5 \%$ as $\mathrm{Cr}^{3+}$ in EMHS [3]. The present study contained less $\mathrm{Cr}$ concentration compared to Golder et al. [3].

Figure 1. Statistics of $\mathrm{Mn}, \mathrm{Ti}, \mathrm{Cu}, \mathrm{Zn}$ and $\mathrm{Ni}$ content in EMHS.

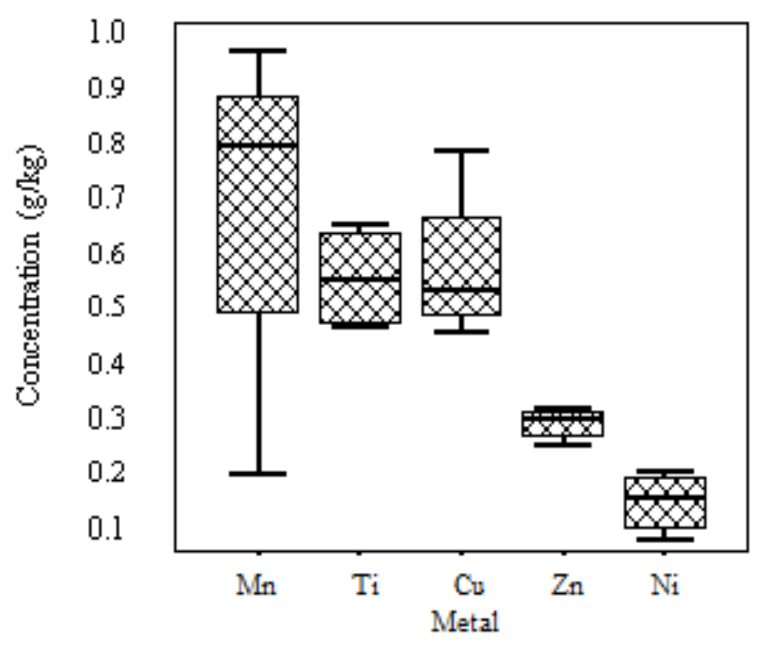

Figure 2. Statistics of Sr, V and Cr content in EMHS.

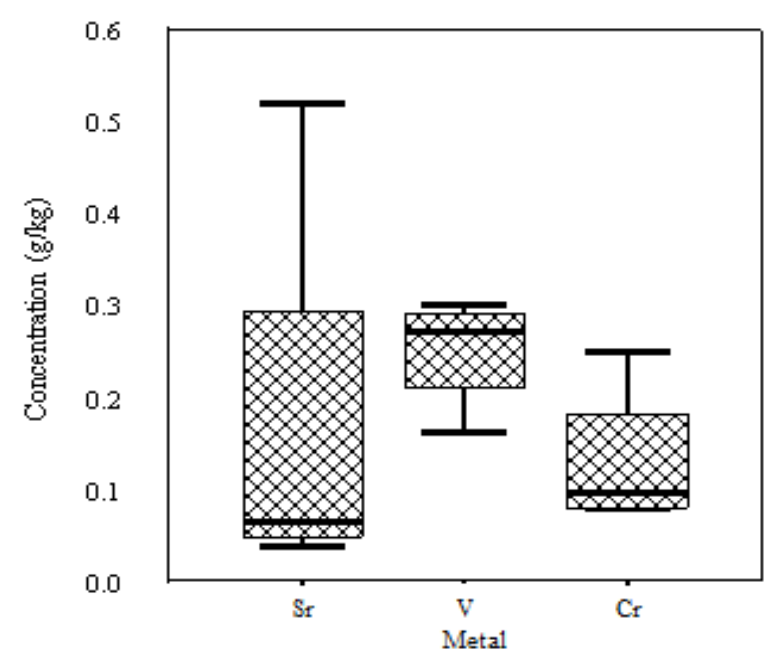

$\mathrm{Nb}, \mathrm{Cd}$ and $\mathrm{Ga}$ content in EMHS ranged from 20-35, 11-18 and 0-33 mg/kg, respectively (Figure 3). $\mathrm{Cd}$ content in EMHS was higher than the recommended value to apply in agricultural land [31]. When $\mathrm{Cd}$ compounds bind with the soil, they can be more easily bio-accumulated or re-dissolved when the soil is disturbed, such as during run-off [2]. Therefore, the use of sludge as a soil conditioner or fertilizer in arable soils can cause severe pollution with $\mathrm{Cd}$, and the production of crops and vegetables may be at a risk. Cd was found to be $3 \mathrm{mg} / \mathrm{kg}$ in dewatered sludge and $5 \mathrm{mg} / \mathrm{kg}$ in dried sludge [7], $6.27 \mathrm{mg} / \mathrm{kg}$ in textile sludge [2] and $5.6 \mathrm{mg} / \mathrm{kg}$ in common effluent plant sludge [11]. Cd content in EMHS was relatively higher than other textile sludge. All heavy metals coming to EMHS stem from different types of salts, dyes and chemicals used at various stages in the textile industry. Moreover, active polymeric species released from the iron electrodes absorbed and adsorbed these metal particles by electrostatic attraction and surface complexation [4]. Excessive accumulation of heavy metals in agricultural soils through sludge disposal may cut the quality and safety of food [15]. 
Figure 3. Statistics of $\mathrm{Zr}, \mathrm{Hg}, \mathrm{Cd}, \mathrm{Nb}$ and $\mathrm{Ga}$ content in EMHS.

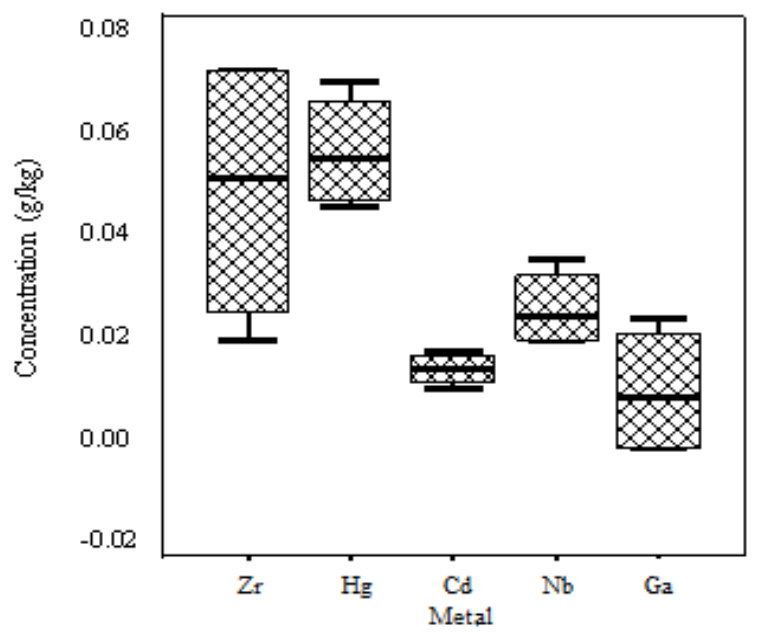

In Table 2, the values of the metal guidelines for land-filling residues were provided. The class I are the values that must not be exceeded to consider waste as one inert residue. If values passed the class I level, the waste needed to be deposited in a special landfill. At the same time, the class II values are the levels classifying the waste as hazardous waste. $\mathrm{Cr}, \mathrm{Ni}, \mathrm{Cu}$ and $\mathrm{Zn}$ content were the criteria to qualify the waste as belonging to one of the different classes [37]. All four metals in the present study were below class II, and hence, we considered EMHS as an inert material of class I that needed to be deposited in controlled landfills.

Pearson correlation analysis of EMHS samples between all the variables and level of significance $(p \leq 0.05$ and $p \leq 0.01$ ) were determined (Table 3). Positive correlation was found between: $\mathrm{Mn}-\mathrm{Zn}$, Mn-V, Mn-Nb, Ti-Cu, Ti-Zr, Zn-V, Zn-Nb, Zn-Ga, Ni-Cd, Sr-Cr, Sr-Hg, Cd-Nb, Cd-Ga and Nb-Ga. Negative correlation was found between: Mn-Sr, Mn-Cr, Mn-Hg, Ti-Zn, Ti-Ni, Ti-Cd, Ti-Nb, Ti-Ga, $\mathrm{Cu}-\mathrm{Ni}$, Cu-Cd, Cu-Nb, Cu-Ga, Zn-Cr, Zn-Zr, Zn-Hg, Sr-V, V-Cr, V-Hg, Cr-Nb, Cr-Ga, Zr-Cd, Zr-Nb and $\mathrm{Zr}-\mathrm{Ga}$.

As EMHS is not suitable for agricultural land application, it can be utilized for other beneficial purposes. One technique is solidification that stabilizes/solidifies components of waste sludge. The solidified products can be disposed of in a secure landfill site or recycled and reused as construction materials, like bricks, concrete or building blocks, if they meet the specific strength requirement [38]. As sludge is a burden for the industry and environment, utilization or reuse of EMHS as construction or building materials is a win-win strategy, because it not only converts the waste materials into useful products, but it also alleviates the sludge disposal problem. The prospective benefits of using sludge as building block additives include immobilizing toxic and heavy metal in the fired matrix, oxidizing organic matter and destroying any pathogen during the firing process and reducing the frost damage, based on the results of several full or bench scale studies $[6,7,39]$. 
Table 2. Concentration of heavy metals in EMHS and different legislations for sludge utilization.

\begin{tabular}{|c|c|c|c|c|c|c|c|c|c|c|c|c|c|}
\hline & Mn & $\mathbf{T i}$ & $\mathbf{C u}$ & Zn & $\mathrm{Ni}$ & Sr & $\mathrm{Zr}$ & $\mathbf{V}$ & $\mathbf{C r}$ & Hg & Cd & Nb & Ga \\
\hline & \multicolumn{7}{|c|}{$\mathrm{g} / \mathrm{kg}$} & \multicolumn{6}{|c|}{$\mathrm{mg} / \mathrm{kg}$} \\
\hline Average & 0.76 & 0.56 & 0.53 & 0.31 & 0.18 & 69.33 & 0.05 & 166.5 & 130 & 55 & 14.5 & 26 & 10.5 \\
\hline Standard Deviation & 0.35 & 0.08 & 0.18 & 0.03 & 0.05 & 18.04 & 0.03 & 112.3 & 81.2 & 10.9 & 3.1 & 7.4 & 12.4 \\
\hline Maximum & 0.98 & 0.67 & 0.78 & 0.34 & 0.24 & 88 & 0.07 & 300 & 250 & 68 & 18 & 35 & 24 \\
\hline Minimum & 0.23 & 0.48 & 0.34 & 0.28 & 0.12 & 52 & 0.02 & 26 & 80 & 45 & 11 & 20 & 0 \\
\hline Landfill Legislation (Class I) (g/kg) [37] & NA & NA & $0-6$ & $0-8$ & $0-2$ & NA & NA & NA & $0-3$ & NA & NA & NA & NA \\
\hline Landfill Legislation (Class II) (g/kg) [37] & NA & NA & $6-60$ & $8-75$ & $2-50$ & NA & NA & NA & $3-50$ & NA & NA & NA & NA \\
\hline Permissible limit in India $(\mathrm{mg} / \mathrm{kg})[31]$ & 400 & NA & $0.2-0.3$ & 300 & NA & NA & NA & NA & NA & NA & $3-6$ & NA & NA \\
\hline SEPAC limit in China $(\mathrm{mg} / \mathrm{kg})[33]$ & 688 & NA & 0.1 & 300 & 26.6 & NA & NA & NA & 250 & NA & 0.6 & NA & NA \\
\hline
\end{tabular}

Table 3. Correlation coefficient matrix of heavy metals in EMHS.

\begin{tabular}{|c|c|c|c|c|c|c|c|c|c|c|c|c|c|}
\hline & Mn & $\mathbf{T i}$ & $\mathbf{C u}$ & Zn & $\mathrm{Ni}$ & $\mathrm{Sr}$ & $\mathbf{V}$ & $\mathrm{Cr}$ & $\mathrm{Zr}$ & $\mathrm{Hg}$ & Cd & $\mathrm{Nb}$ & Ga \\
\hline $\mathrm{Mn}$ & 1 & & & & & & & & & & & & \\
\hline $\mathrm{Ti}$ & -0.498 & 1 & & & & & & & & & & & \\
\hline $\mathrm{Cu}$ & 0.071 & 0.827 & 1 & & & & & & & & & & \\
\hline $\mathrm{Zn}$ & 0.948 & -0.738 & -0.231 & 1 & & & & & & & & & \\
\hline $\mathrm{Ni}$ & -0.438 & -0.532 & -0.872 & -0.130 & 1 & & & & & & & & \\
\hline $\mathrm{Sr}$ & $-0.968 *$ & 0.397 & -0.184 & -0.907 & 0.453 & 1 & & & & & & & \\
\hline $\mathrm{V}$ & 0.886 & -0.238 & 0.327 & 0.802 & -0.492 & $-0.973 *$ & 1 & & & & & & \\
\hline $\mathrm{Cr}$ & $-0.973 *$ & 0.593 & 0.040 & $-0.977 *$ & 0.270 & $0.975 *$ & -0.911 & 1 & & & & & \\
\hline $\mathrm{Zr}$ & -0.598 & $0.986 *$ & 0.739 & -0.819 & -0.451 & 0.526 & -0.387 & 0.702 & 1 & & & & \\
\hline $\mathrm{Hg}$ & -0.624 & 0.193 & -0.241 & -0.614 & 0.203 & 0.794 & -0.893 & 0.740 & 0.348 & 1 & & & \\
\hline $\mathrm{Cd}$ & 0.343 & $-0.978 *$ & -0.891 & 0.621 & 0.686 & -0.271 & 0.138 & -0.475 & $-0.958 *$ & -0.186 & 1 & & \\
\hline $\mathrm{Nb}$ & 0.676 & -0.897 & -0.623 & 0.810 & 0.176 & -0.510 & 0.306 & -0.670 & -0.880 & -0.062 & 0.788 & 1 & \\
\hline $\mathrm{Ga}$ & 0.583 & $-0.983 *$ & -0.741 & 0.810 & 0.471 & -0.521 & 0.390 & -0.697 & $-0.999 * *$ & -0.370 & $0.962 *$ & 0.858 & 1 \\
\hline
\end{tabular}

* Correlation is significant at the 0.05 level (2-tailed); ** Correlation is significant at the 0.01 level (2-tailed). 


\section{Experimental Section}

\subsection{Samples Collection and Preparation}

The wet EMHS samples $(n=15)$ were collected at four-month intervals in 2011 from Adury Knit Composite Ltd., (Geographic Location: $24^{\circ} 02^{\prime} \mathrm{N}$ latitude and $90^{\circ} 44^{\prime}$ E longitude) Shibpur, Narshingdi, Bangladesh. EMHS was generated in this textile industry after the treatment of effluent by EC. Sampling criteria based on full scale operation and effluent treatment by the industry. The samples were kept in a separate plastic container and stored at ambient temperature prior to analysis. EMHS samples were sun-dried and made into powder using a grinder of an aluminum oxide ball material. Samples that passed through $0.853 \mathrm{~mm}$ sieve were taken for heavy metal analysis by EDXRF.

\subsection{Experiment}

ARL QUANT'X EDXRF (Thermo Scientific, USA), equipped with a Rhodium (Rh) anode along with an assembly of eight filters (Al, Cellulose, $\mathrm{Cu}$ thick, $\mathrm{Cu}$ thin, No, Pd medium, Pd thick and $\mathrm{Pd}$ thin) and a $\mathrm{Si}(\mathrm{Li})$ detector (with a $15 \mathrm{~mm}^{2}$ area and $\leq 76$ micron Beryllium window) was used. $\mathrm{Cu}$ thin, $\mathrm{Cu}$ thick, Pd thin and Pd thick filters were applied in the present study. It operated at $24 \mathrm{~V} \mathrm{DC}$ and generated up to $50 \mathrm{kV}$. For excitation, $80^{\circ}$ geometry among the X-ray tube, sample and detector was maintained as X-ray optics. The distance from the sample to X-ray tube target was $54.1 \mathrm{~mm}$. The Si (Li) detector had a resolution of $155 \mathrm{eV}$ for $5.9 \mathrm{keV}$ X-ray at 1500 counts per second (cps) and was capable of acquiring a spectrum in the 1 to $40 \mathrm{keV}$ energy region. In the sample chamber, samples (5-8 mg) were placed in Teflon cup assemblies fitted with Mylar film for support. The measurements were carried out in the air, and helium gas was used to flush the switch. The samples were excited for $300 \mathrm{~s}$. The data acquired were processed with the help of an attached computer. The resulting intensity was expressed in counts per second (cps). The fundamental parameters (FP) approach was used for the quantitative analysis of samples. The FP model was calibrated using the National Institute of Standards \& Technology traceable certified reference standards (NIST 2781). A quick and straightforward FP calibration curve was generated, and accuracy was within $5 \%$ to $10 \%$.

\section{Conclusions}

Discharges of heavy metals containing sludge from textile industries are a very strong issue in the current industrial time. A wide variety of sludge disposal routes have been adopted, as dictated by local conditions. An EDXRF instrument was applied in the present study to determine heavy metal content in EMHS from the textile industry. Thirteen heavy metals were found, and among these, Mn, $\mathrm{Ni}, \mathrm{Cu}, \mathrm{Zn}$ and $\mathrm{Cd}$ exceeded the permissible limit to apply in agricultural fields as nutrient supplements. Long-term exposure to metals from the sludge in soil may contaminate it, change the soil structure and, thus, make it harmful for cultivation. EMHS was grouped as an inert waste that can be deposited in controlled landfill. Further research needs to be carried out to analyze the leaching potential of heavy metals from tailings, as well as reuse potentialities of EMHS. Environmental monitoring programs need to be generally designed to cover a large number of different types of 
characteristic variables, which may be required to assess the contamination status of the system and the contaminant sources from their remediation point of view.

\section{Acknowledgement}

The first author is pleased to acknowledge the financial support from the Ministry of Science, Information and Communication Technology, Peoples Republic of Bangladesh, under the National Science, Information and Communication Technology (NSICT) Fellowship. The authors are grateful for the thoughtful comments of two anonymous reviewers.

\section{References}

1. Rahman, S.H.; Neelormi, S.; Tareq, S.M. Environmental impact assessments of textile and dyeing industries on ecosystem of karnopara canal at Savar, Bangladesh. Jahangirnagar Univ. J. Sci. 2008, 31, 19-32.

2. Islam, M.M.; Halim, M.A.; Safiullah, S.; Hoque, S.A.M.W.; Islam, M.S. Heavy metal (Pb, Cd, $\mathrm{Zn}, \mathrm{Cu}, \mathrm{Cr}, \mathrm{Fe}$ and $\mathrm{Mn}$ ) content in textile sludge in Gazipur, Bangladesh. Res. J. Environ. Sci. 2009, 3, 311-315.

3. Golder, A.K.; Samanta, A.N.; Ray, S. Anionic reactive dye removal from aqueous solution using a new adsorbent-sludge generated in removal of heavy metal by electrocoagulation. Chem. Eng. J. 2006, 122, 107-115.

4. Mollah, M.Y.A.; Schennach, R.; Parga, J.R.; Cocke, D.L. Electrocoagulation (EC)-science and applications. J. Hazard. Mater. 2001, 84, 29-41.

5. Thomson, J.C.; Azariah, J.; Viji, A.G.R. Impact of textile industries on river Noyyal and riverine groundwater quality in Tirupur, India. Environ. Monit. Assess. 1999, 18, 359-368.

6. Lin, D.F.; Weng, C.H. Use of sewage sludge ash as brick material. J. Environ. Eng. 2001, 127, 922-727.

7. Weng, C.H.; Lin, D.F.; Chiang, P.C. Utilization of sludge as brick materials. Adv. Environ. Res. 2003, 7, 679-685.

8. Chen, Y.; Wang, C.; Wang, Z. Residues and source identification of persistent organic pollutants in farmland soils irrigated by effluents from biological treatment plants. Environ. Int. 2005, 31, 778-783.

9. Manahan, S.E. Environmental Chemistry, 8th ed.; Lewis Publisher: Boca Raton, Florida, FL, USA, 2005; pp. 110-117.

10. Balasubramania, J.; Sabumon, P.C.; Lazar, J.U.; Ilangovan, R. Reuse of textile effluent treatment plant sludge in building materials. Waste Manag. 2006, 26, 22-28.

11. Baskar, R.; Begum, K.M.M.S.; Sundaram, S. Characterization and reuse of textile effluent treatment plant waste sludge in clay bricks. J. Univ. Chem. Technol. Metall. 2006, 41, 473-478.

12. Patel, H.; Pandey, S. Exploring the reuse potential of chemical sludge from textile wastewater treatment plants in India-A hazardous waste. Am. J. Environ. Sci. 2009, 5, 106-110.

13. Wilson, B.; Pyatt, F.B. Heavy metal dispersion, persistence, and bioaccumulation around an ancient copper mine situated in Anglesey, UK. Ecotoxicol. Environ. Saf. 2007, 66, 224-231. 
14. Singh, K.P.; Mohan, D.; Sinha, S.; Dalwani, R. Impact assessment of treated/untreated wastewater toxicants discharged by sewage treatment plants on health, agricultural and environmental quality in the wastewater disposal area. Chemosphere 2004, 55, 227-255.

15. Muchuweti, M.; Birkett, J.W.; Chinyanga, E.; Zvauya, R.; Scrimshaw, M.D.; Lester, J.N. Heavy metal content of vegetables irrigated with mixture of wastewater and sewage sludge in Zimbabwe: Implications for human health. Agr. Ecosyst. Environ. 2006, 112, 41-48.

16. Senesi, G.S.; Baldassarre, G.; Senesi, N.; Redina, B. Trace element inputs into soils by anthropogenic activities and implications for human health. Chemosphere 1999, 39, 343-377.

17. Turkdogan, M.K.; Kilicel, F.; Kara, K.; Tuncer, I. Heavy metals in soil, vegetables and fruits in the endemic upper gastrointestinal cancer region of Turkey. Environ. Toxicol. Pharmacol. 2002, $13,175-179$.

18. Kocasoy, G.; Sahin, V. Heavy metal removal from industrial wastewater by clinoptilolite. J. Environ. Sci. Health 2007, 42, 2139-2146.

19. Santra, S.; Mitra, D.; Sarkar, M.; Bhattacharya, D.; Denker, A.; Opitz-Coutureau, J.; Rauschenberg, J. Analysis of some coins by energy dispersive X-ray fluorescence (EDXRF) and high energy particle induced X-ray emission (PIXE) techniques. Nucl. Instrum. Methods Phys. Res. Sect. B 2005, 229, 465-470.

20. Singh, V.; Agrawal, H.M.; Joshi, G.C.; Sudershan, M.; Sinha, A.K. Elemental profile of agricultural soil by the EDXRF technique and use of the Principal Component Analysis (PCA) method to interpret the complex data. Appl. Radiat. Isot. 2011, 69, 969-974.

21. Polat, R.; Gürol, A.; Karabulut, A.; Ertuğrul, M. Elemental composition of cement Kiln dust, raw material and cement from coal-fried cement factory using energy dispersive X-ray fluorescence spectroscopy. J. Quant. Spectrosc. Radiat. Transfer 2004, 83, 377-385.

22. Buduk, G.; Karabulut, A. X ray flurocense analysis of malachite ore concentrates in the Naruma Region, Spain. Spectrochim. Acta B 1999, 203, 119-124.

23. Yu, K.N.; Yeung, Z.; Leea, L.; Stokes, M.J.; Kwok, R.C.W. Determination of multi-element profiles of soil using energy-dispersive X-ray fluorescenc (EDXRF). Appl. Radiat. Isot. 2002, 57, 279-284.

24. Vijayan, V.; Rautray, T.R.; Basa, D.K. EDXRF study of Indian punch-marked silver coins. Nucl. Instr. Meth. 2004, 225, 353-356.

25. Obiajunwa, E.I.; Pelemo, D.A.; Owolabi, S.A.; Fasasi, M.K.; Johnson-Fatokun, F.O. Characterisation of heavy metal pollutants of soils and sediments around a crude-oil production terminal using EDXRF. Nucl. Instrum. Methods Phys. Res. Sect. B 2002, 194, 61-64.

26. Obiajunwa, E.I.; Johnson-Fatokun, F.O.; Olaniyi, H.B.; Olowole, A.F. Determination of the elemental composition of aerosol samples in the working environment of a secondary lead smelting company in Nigeria using EDXRF technique. Nucl. Instrum. Methods Phys. Res. Sect. B 2002, 194, 65-68.

27. Joshi, G.C.; Agrawal, H.M.; Mohanta, B.; Sudarshan, M.; Sinha, A.K. Elemental study of Nainital Lake water by EDXRF. Nucl. Instrum. Methods Phys. Res. Sect. B 2006, 251, 223-226.

28. Pitarch, A.; Queralt, I. Energy dispersive X-ray fluorescence analysis of ancient coins: The case of Greek silver drachmae from the Emporion site in Spain. Nucl. Instrum. Methods Phys. Res. Sect. B 2010, 268, 1682-1685. 
29. Elossaief, M.; Kallel, N.; Yaacoubi, A.; Benzina, M. Mineralogical identification, spectostoscopic characterization, and potential environmental uses of natural clay minerals on chromate removal from aquous solutions. Chem. Eng. J. 2011, 168, 1024-1031.

30. Akpan, I.O.; Amodu, A.E.; Akpan, A.E. Elemental analysis of limestone samples from Obajana and Mfamosing limestone deposits, Nigeria using nuclear technique. Appl. Radiat. Isot. 2011, 69, 1355-1358.

31. Awashthi, S.K. Prevention of Food Adulteration Act no 37 of 1954 Central and State Rules as Amended for 1999, 3rd ed.; Ashoka Law House: New Delhi, India, 2000; pp. 1-71.

32. CCME (Canadian Council of Ministers of the Environment). Canadian Soil Quality Guidelines for the Protection of the Environment and Human Health; Canadian Council of Ministers of the Environment: Winnipeg, Canada, 2003; 1-175.

33. SEPAC (State Environmental Protection Administration of China). Chinese Environmental Quality Standard for Soils; State of Environment Protection Bureau: Beijing, China, 1995; 1-4.

34. Su, D.C.; Wong, J.W.C. Chemical speciation and phytoavailability of $\mathrm{Zn}, \mathrm{Cu}, \mathrm{Ni}$ and $\mathrm{Cd}$ in soil amended with fly ash-stabilized sewage sludge. Environ. Int. 2003, 29, 895-900.

35. Udom, B.E.; Mbagwu, J.S.C.; Adesodun, J.K.; Agbim, N.N. Distributions of zinc, copper, cadmium and lead in a tropical ultisol after long-term disposal of sewage. Environ. Int. 2004, 30, $467-470$.

36. Dai, J.Y.; Xu, M.Q.; Chen, J.P.; Yang, X.P.; Ke, Z.S. PCDD/F, PAH and heavy metals in the sewage sludge from six wastewater treatment plants in Beijing China. Chemosphere 2007, 66, 353-361.

37. Gonzalez-Fernandez, O.; Aueralt, I.; Carvalho, M.L.; Garcia, G. Elemetal analysis of mining wastes by energy dispersive X ray fluorescence (EDXRF). Nucl. Instrum. Methods Phys. Res. Sect. B 2007, 262, 81-86.

38. Rahmat, M.N. Development of environmentally friendly building material: Analysis of the use of solidified industrial waste. Available online: http://130.203.133.150/showciting?cid=13498366 (accessed on 8 October, 2012).

39. Tay, J.H.; Show, K.Y. Constructive Sludge Disposal Option Converting Sludge into Innovative Civil Engineering Materials. In Proceedings of 7th International Association on Water Quality (IAWQ). Asia-Pacific Regional Conference, Taipei, Taiwan, 1999; pp. 1023-1028.

(C) 2012 by the authors; licensee MDPI, Basel, Switzerland. This article is an open access article distributed under the terms and conditions of the Creative Commons Attribution license (http://creativecommons.org/licenses/by/3.0/). 